\title{
The Athenian Calendar of Sacrifices: A New Fragment from the Athenian Agora
}

Laura Gawlinski

Loyola University Chicago, Igawlinski@luc.edu

Follow this and additional works at: https://ecommons.luc.edu/classicalstudies_facpubs

Part of the Classics Commons

\section{Recommended Citation}

Gawlinski, L. "The Athenian Calendar of Sacrifices: A New Fragment from the Athenian Agora." Hesperia 76, 2012.

This Article is brought to you for free and open access by the Faculty Publications and Other Works by Department at Loyola eCommons. It has been accepted for inclusion in Classical Studies: Faculty Publications and Other Works by an authorized administrator of Loyola eCommons. For more information, please contact ecommons@luc.edu. \section{(c) $($ () $\ominus$}

This work is licensed under a Creative Commons Attribution-Noncommercial-No Derivative Works 3.0 License. (c) The American School of Classical Studies at Athens, 2007. 
HESPERIA 76 (2007)

Pages 37-55

\title{
THE ATHENIAN CALENDAR OF SACRIFICES
}

\section{A New Fragment from the Athenian Agora}

\begin{abstract}
Presented here is the editio princeps of a new fragment of the late-5th-century в.c. Athenian calendar of sacrifices. The fragment, Agora I 7577, was discovered during excavations conducted in the Athenian Agora by the American School of Classical Studies. Inscribed on both faces (Face A: 403-399 B.c., Face B: 410-404 B.c.), it is associated with, but does not join, the group of fragments of Athenian legal inscriptions often referred to as the Law Code of Nikomachos. The text provides important additional evidence for the form of the calendar and the manner of its publication, and casts new light on broader issues of Athenian cult and topography.
\end{abstract}

In the late 5th century B.c. a monumental change occurred in the presentation of Athenian law, when the Athenians decided that it was time to scrutinize and reinscribe the laws of Solon. ${ }^{1}$ This work was commissioned in two stages, first from 410 to 404 B.c. under the democracy, and then again from 403 to 399 B.C., after the fall of the Thirty and the restoration of the democracy. Although the Athenians continued to attribute their laws to Solon, in modern scholarship the results of the republication are usually referred to as the "Law Code of Nikomachos," so named for the editor (anagrapheus) Nikomachos, one of the officials chosen to work on the project, who was accused by Lysias of mishandling the publication. ${ }^{2}$

Included in the new code was a calendar of sacrifices. The purpose of such calendars was to record the deities and their intended offerings, the

1. I would first like to thank John Camp, director of the Agora Excavations, for introducing me to sacred law and giving me the opportunity to publish this fragment. Thanks are also due to other members of the Agora staff who aided in the completion of this article: Craig Mauzy, Jan Jordan, and Sylvie Dumont. John Camp, Kevin Clinton, and Molly Richardson patiently read multiple drafts and offered useful insights. The recommendations of the anonymous Hesperia referees also greatly improved this work. Stephen Lambert kindly shared an advance copy of his work on the calendar with me. An earlier version of this paper was presented in 2003 at a colloquium organized by James Sickinger at the American School of
Classical Studies at Athens entitled "New Studies in Greek Epigraphy." I am grateful for the comments of the participants.

2. Lys. 30. For an examination of this speech, see Todd 1996. For more on the code in general, see Dow 1960 (with bibliography through 1959), Dow 1961, Fingarette 1971, Clinton 1982, Robertson 1990, and Lambert 2002. 


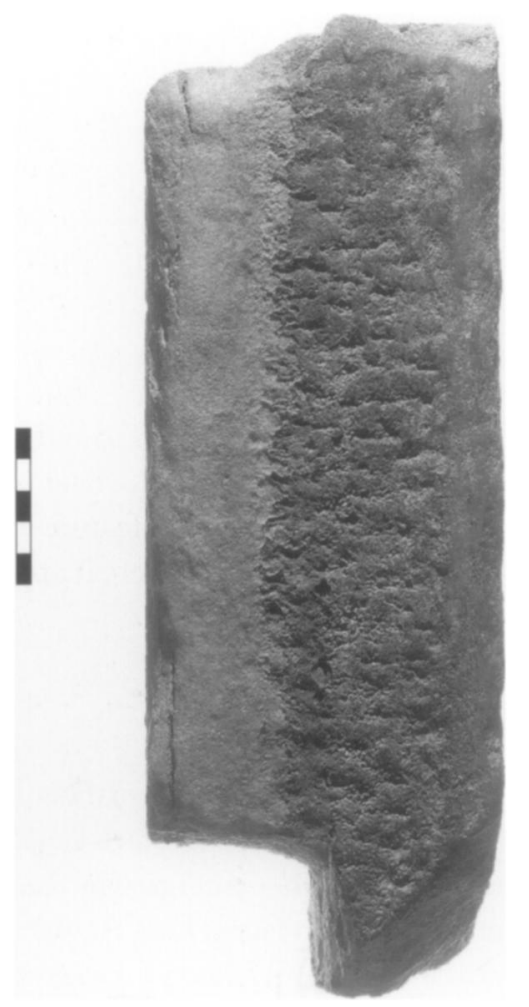

price to be paid by the city for these offerings and other incidentals, and the date on which each sacrifice was to occur. This particular calendar is generally agreed to have been displayed in the Athenian Agora, and was most likely housed in the Stoa Basileios. At least part of the calendar was inscribed on a series of stelai provided with anathyrosis and joined by clamps to form a continuous wall. Both faces of these stelai originally carried the list of sacrifices inscribed between 410 and 404 in the Attic script; Face A, however, was later erased and then reinscribed between 403 and 399 in the newly adopted Ionic script. ${ }^{3}$ The 13 known fragments of the calendar, in various states of preservation, have recently been reexamined in a new study by Stephen Lambert. ${ }^{4}$

The most recent addition to this group of fragments was discovered on June 29, 1993, during the American excavations in the Athenian Agora. Found built into a Late Roman drain in section $\mathrm{B} \Gamma$ to the north of the modern railway line (I/4-4/7, elevation $51.96 \mathrm{~m}$ ), it lay about $5 \mathrm{~m}$ to the west of its proposed original location in the Stoa Basileios.

The fragment, Agora I 7577 (p.H. 0.33, p.W. 0.135, Th. 0.116 m), is inscribed on white "Pentelic" marble. On one side it is treated with two bands of anathyrosis, showing that it adjoined another stele (Fig. 1). It is broken on all other sides, resulting in a piece of irregular triangular shape, and has water damage and traces of mortar from its reuse in the drain. The bottom of Face A (the Ionic face) is broken off, and the preserved height of Face B (the Attic face) is $0.07 \mathrm{~m}$ greater than that of Face A. Despite this difference in the preserved height of the two faces, approximately the same number of lines are legible on each face.

Damage to the upper half of Face A has left much of the surface quite friable. The right edge and bottom are battered and a shallow gouge has obliterated some letters in the center. The lower half is encrusted with a
Figure 1. Agora I 7577, preserved side with bands of anathyrosis. Face A (Ionic) left, Face B (Attic) right. Photo courtesy American School of Classical Studies at Athens, Agora Excavations

3. I follow Lambert's (2002) titling of Faces A (Ionic) and B (Attic), a sequence that reflects the original, pre-erasure order of inscribing. Certain features, in particular the decorative fascia, suggest that Face A was always intended to be the primary face and was the first to be inscribed with the calendar in the Attic alphabet. For discussion of the erasure and the order of inscribing, see Dow 1961, pp. 6365, 70-72; Lambert 2002, p. 355.

4. Lambert 2002, with additional bibliography and full discussion of the general features of the calendar. I refer to the fragments throughout by Lambert's numbering; the present fragment is no. 5 (L5). Face B of fragment L3 (I 727) contains text of trierarchic law, not sacrificial calendar, and is not included in this discussion. For that text, see $I G \mathrm{I}^{3} 236 \mathrm{a}$. For the relationship of $I G \mathrm{I}^{3} 236 \mathrm{~b}$ on which only Face B is preserved, see Lambert 2004a, no. 2, pp. 182-183. 
5. I thank Agora conservators Julie Unruh and Karen Abend for reexamining the stone.

6. Other fragments with an inscribed horizontal line on the Ionic face are $\mathrm{L} 1\left(I G \mathrm{II}^{2} 1357\right.$ a [EM 8001 and 6721]), L2 (Agora I 4310), and L3 (Agora I 727).

7. Other fragments with anathyrosis are $\mathrm{L} 1\left(I G \mathrm{II}^{2} 1357\right.$ a [EM 8001 and 6721]; both faces), L2 (Agora I 4310; Ionic face only), L3 (Agora I 727; both faces), and L8 (Agora I 251; probably Ionic face only).

8. Dow 1961, p. 63; Lambert 2002, pp. 361-362.

9. Dow 1961, p. 64. Fragment L1 (IG $\mathrm{II}^{2} 1357$ a [EM 8001 and 6721]) also has anathyrosis adjacent to both faces, but the band next to the Attic face is too worn to allow any conclusion about its original projection; Dow 1961, pp. 60-61.

10. Dow 1961, p. 58; Lambert 2002, pp. 355-356, with n. 17.

11. Dow's "Thicker Wall" or " 120 mm Wall"; Lambert's "Group A." Lambert's numbering of the present fragment (L5) tacitly implies that he believes it belongs to Group A, since it appears among the other Group $\mathrm{A}$ fragments $(\mathrm{L} 1-3,6,7)$.

12. Measurements according to Lambert 2002, pp. 358-360.

13. For a description of the two separate lettering styles found on the fragments, see Lambert 2002, pp. 355-356. thin, dark coating of mortar, which is also found between the bands of anathyrosis. The encrustation generally does not affect the reading of the stone, and its removal would probably cause even more damage to the surface. ${ }^{5}$ The thin band of anathyrosis adjacent to this face is worn extraordinarily smooth. Face B is especially worn at the upper left, leaving only the lower right portion of the surface legible. The left edge is battered, making some of the numerals difficult to read. The preserved portion is very clear, however, with large, deeply cut letters and no significant encrustation or wear.

Several features of the inscription mark it as a fragment of the late5 th-century law code. First, it is opisthographic, inscribed on one face in the Attic alphabet and on the other in the Ionic. Second, the Ionic face preserves part of an inscribed horizontal line, a feature also found on the Ionic face of other fragments of the calendar, where it appears either at the top of the stone, to separate the text from a heading above, or lower down, to distinguish different portions of the text. ${ }^{6}$ Finally, the preserved side is treated with two bands of anathyrosis (Fig. 1). That it has two bands, one adjacent to each of the faces, is significant, since of the other four fragments with anathyrosis, two have it only next to the Ionic face. ${ }^{7}$ On the present fragment the bands are of different widths, that next to the Ionic face being thinner $(0.021$ vs. $0.035 \mathrm{~m})$. This difference in width cannot be explained by the fact that the Ionic face had been previously erased, however, for the depth of the erasure was estimated by Dow to be only $1 \mathrm{~mm}$ in the case of fragment L3 (Agora I 727). ${ }^{8}$ The projection of the two bands cannot be measured exactly, but they are approximately even and the stone lies flat when placed on the preserved side. This feature is in marked contrast to fragment L3, on which the band of anathyrosis next to the Ionic face projects further than that next to the Attic face. ${ }^{9}$

The existing fragments of the calendar have previously been divided, on the basis of thickness and lettering styles, into two groups, described as separate walls by Dow and as "stele-series" by Lambert. ${ }^{10}$ The thickness of the fragment published here $(11.6 \mathrm{~cm})$ seems to indicate that it should be associated with the thicker series. ${ }^{11}$ Although it is about $3 \mathrm{~mm}$ thinner than the thinnest fragment in that group (L1 [IG II 1357 a (EM 8001 and $6721)], 11.9 \mathrm{~cm}$ ), it is more than $2 \mathrm{~cm}$ thicker than the thickest measurable fragment in the thinner group (L8 [Agora I 251], $9.4 \mathrm{~cm}$ ). ${ }^{12}$ The lettering style of the present fragment, however, is not completely consistent with that of the other fragments in the thicker group. ${ }^{13}$ These are generally more carefully inscribed than the thinner fragments and employ stoichedon on both faces, while neither face of the thinner fragments is stoichedon. On the present fragment, the Attic text on Face B is stoichedon, but the Ionic text on Face $A$ is inscribed in a haphazard manner that resembles more closely the Ionic face of the thinner fragments. Non-stoichedon text is, however, found at least once among the thicker fragments, under the horizontal line inscribed on Face A of fragment L1. A dividing line is also present on the Ionic face of the present fragment, and if this line is used in the same way as that on fragment L1 (see below), then the fact that the text beneath it is not stoichedon is less problematic.

The text printed here is based on repeated examination of the stone in various lights. Since the two faces of the inscription were the result of two processes of publication in antiquity, I present the text of each face separately. 


\section{FACE A (IONIC)}

Agora I 7577, Face A

Fig. 2

P.H. 0.26, p.W. $0.135 \mathrm{~m}$

L.H. 0.007-0.009; omega $0.006 \mathrm{~m}$. Average letter space $0.01 \mathrm{~m}$. Interlinear spacing $0.002-0.003 \mathrm{~m}$. Min. space between cols. I and II $0.019 \mathrm{~m}$.

403-399 в.с.

Non-stoich.

uninscribed vertical surface $0.075 \mathrm{~m}$

\begin{tabular}{|c|c|c|c|}
\hline & $\begin{array}{l}\text { Col. I } \\
\text { amounts }\end{array}$ & $\begin{array}{l}\text { Col. II } \\
\text { amount }\end{array}$ & \\
\hline & 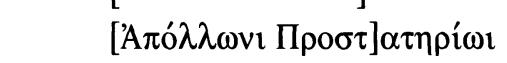 & {$[-2-4--]$} & {$[\ldots-\ldots \ldots \ldots$} \\
\hline & 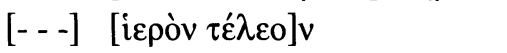 & {$[-2-4--]$} & {$[\ldots \ldots \ldots-\ldots]$} \\
\hline & 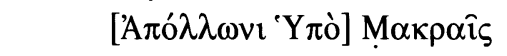 & {$[-2-4--]$} & {$[\ldots \ldots \ldots-\ldots]$} \\
\hline 5 & 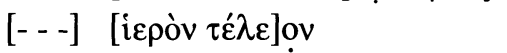 & {$[-2-4--]$} & {$[\ldots \ldots \ldots . . .-1]$} \\
\hline & 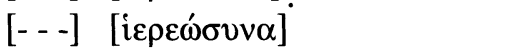 & {$[-2-4--]$} & {$[-\ldots \ldots \ldots . .-1]$} \\
\hline & 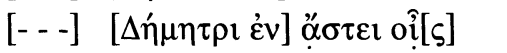 & {$[-2-4--]$} & {$[\ldots \ldots \ldots . . .-1]$} \\
\hline & 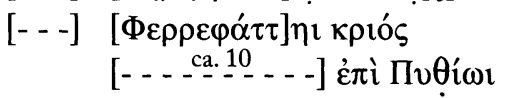 & $\left.\begin{array}{l}\Gamma\left[\begin{array}{l}2-3 \\
2-\end{array}\right] \\
-[-3-\end{array}\right]$ & 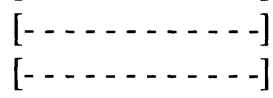 \\
\hline 10 & 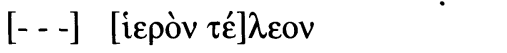 & 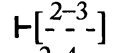 & {$[\ldots \ldots \ldots . . .-\ldots]$} \\
\hline & 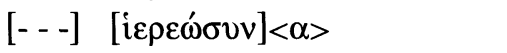 & {$[-2-4--]$} & {$[-\cdots$} \\
\hline & 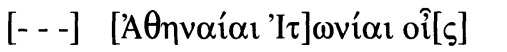 & {$[-2-4--]$} & {$[-\ldots-\ldots-\ldots-\ldots]$} \\
\hline & 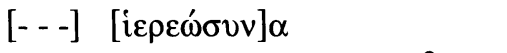 & {$[-2-4--]$} & {$[-\cdots$} \\
\hline & 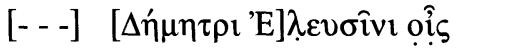 & {$[-2-4-1]$} & {$[\cdots-\cdots$} \\
\hline 15 & {$[\Phi \varepsilon \rho \rho \varepsilon \varphi \alpha ́ \tau \tau] \eta ฺ \imath$} & {$[-\stackrel{2-4}{-2}-]$} & {$[\cdots-\cdots$} \\
\hline & 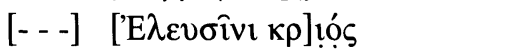 & {$[-2-4--]$} & {$[\ldots \ldots \ldots \ldots$} \\
\hline
\end{tabular}

\section{Epigraphical Commentary}

Line 4. Of the dotted mu only the final diagonal stroke is visible. The sigma is represented only by the upper horizontal stroke and the angle where it meets the diagonal stroke.

Line 5. Of the dotted omicron only the right lower part of a round letter survives.

Line 7. Of the dotted alpha only the bottom of a diagonal stroke sloping down from left to right remains. Of the dotted iota only the lower part of the vertical stroke is preserved.

Line 9. The upsilon is severely damaged, so that the only deep traces remaining are a small dot at the bottom of the vertical stroke and another at the upper end of the right diagonal stroke. The central dot of the theta is either not preserved or was never cut.

Line 10. The form of the lambda, with diagonal strokes bowed outward instead of straight, is unusual. The epsilon and omicron were cut so close to one another that they touch.

Line 11. The crossbar of the alpha was omitted by the cutter, and the diagonal strokes bow outward as in the lambda of line 10 .

Line 12. Only the right half of the omega is preserved. Of the alpha only the interior of the upper triangular area survives. 
Figure 2. Agora I 7577, Face A

(Ionic). Photo courtesy American School of Classical Studies at Athens, Agora Excavations

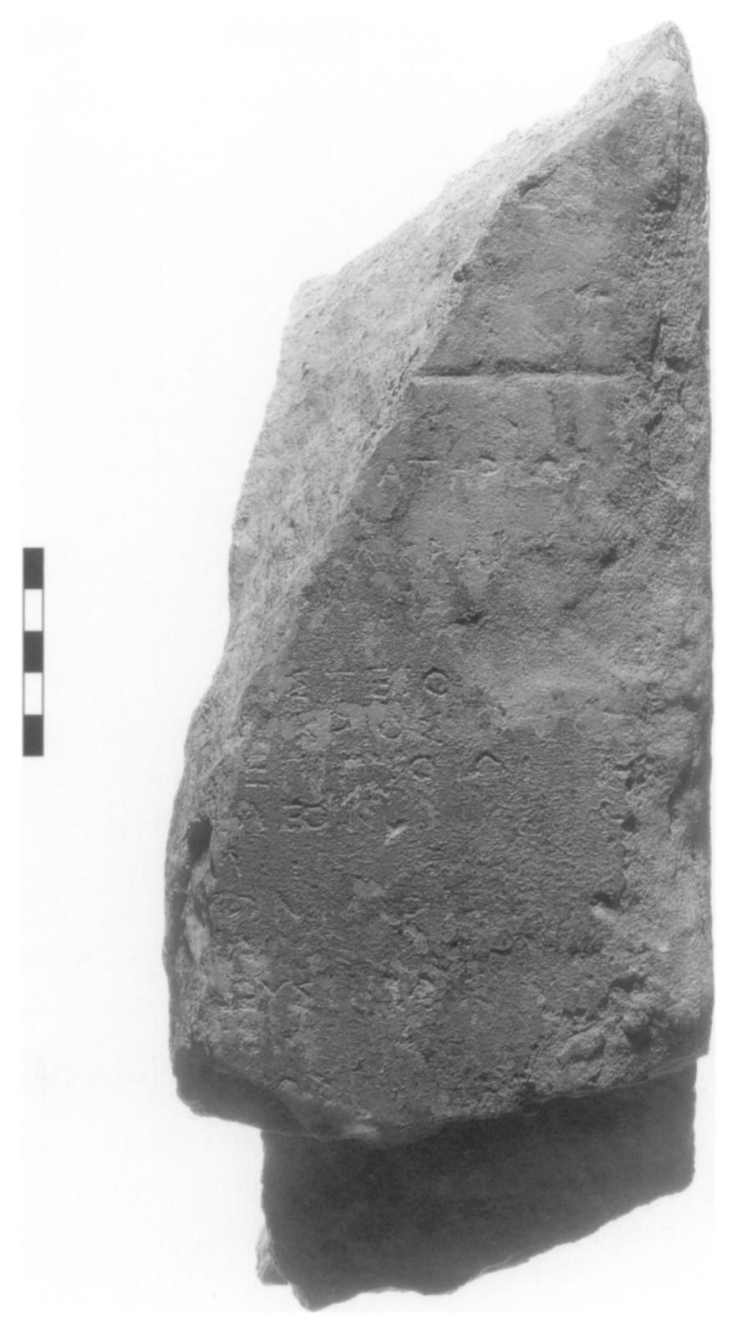

Line 14. Of the dotted lambda there remains only the bottom of a diagonal stroke sloping down from left to right. Of the dotted omicron only the top of a round letter survives. Of the dotted iota most of the vertical stroke survives, but the surrounding surface is damaged.

Line 15. The crossbar of the dotted eta either is not preserved or was never inscribed.

Line 16. Of the dotted iota only the very top of a vertical stroke survives. Of the dotted omicron only the top of a round letter is visible above the break in the stone.

\section{TransLation}

Column I: For Apollo Prostaterios, a full-grown offering, [amount]; for Apollo Hupo Makrais, a full-grown offering, [amount]; hierosyna, [amount]; for Demeter in the city, a sheep, [amount]; for Pherrephatte, a ram, [amount]; for [deity] by the Pythion, a full-grown offering, [amount]; bierosyna, [amount]; for Athena Itonia, a sheep, [amount]; bierosyna, [amount]; for Demeter at Eleusis, a sheep, [amount]; for Pherrephatte at Eleusis, a ram, [amount] 


\section{COMMENTARY}

The text of Face A, the Ionic face, is not very neatly inscribed. It is not stoichedon, and the letters appear to be shallowly cut. Some letters are so close to one another that they touch, as in the case of the epsilon and omicron in line 10. The variation in letter heights, interlinear spacing, and spacing between letters suggests that the inscribing of this face was carried out less conscientiously than that of the Attic face.

Portions of two columns are preserved: on the left, a list with the ends of the names of deities in the dative case and their associated offerings in the nominative; and on the right, a partially preserved list of amounts belonging to a second list of deities and offerings, now missing. This second column would have extended onto the next stone to the right, the evidence for which is provided by the anathyrosis on the side of the fragment.

The most noticeable feature of this face is the thin horizontal line inscribed toward the top of the fragment (p.L. 0.051, W. $0.003 \mathrm{~m}$ ). There are $7.5 \mathrm{~cm}$ of uninscribed surface above the line, but the stone is preserved to a greater height behind the face, indicating that there were originally at least $9.2 \mathrm{~cm}$ of stone above the line. This line, when found on the Ionic face of other fragments, is used to separate the main body of the calendar from other information. It occurs in two places: near the top of the stone, where it separates headings from the text beneath, and lower down, where it separates text above from different text below. Fragments L2 and L3 (Agora I 4310 and I 727) carry a heading above the line, in each case a biennial rubric. Below the line on fragment $\mathrm{L} 1\left(I G \mathrm{II}^{2} 1357\right.$ a [EM 8001 and 6721]), a list of items appears. Its relationship to the calendar above the line is unclear; it may have been set apart because it did not fit into a regular annual or biennial system. ${ }^{14}$

Although the uninscribed space above the line on the present fragment is consistent with that found after the ends of headings, as for example above the first column of fragment L3, the line here is more likely to represent a lower dividing line. A fascia appears just above the heading on the fragments with an upper dividing line (L2 and L3); its absence in the uninscribed space above the line on this fragment seems to indicate that this was not a line for a heading. Here the uninscribed space resembles that found above the line at the end of the third column on fragment L1, where uninscribed surface is found to the right of the final item of the text of the calendar itself.

Like the text below the line on fragment L1, the text of the present fragment is not stoichedon, as one would expect if it belongs to the series of thicker stelai. Unlike the text below the line on L1, however, the format of this text is more clearly calendrical, as the list of deities and offerings in column I and the traces of amounts preserved at the beginning of column II make clear. The spacing between the columns on the present fragment appears similar to that on other fragments of the calendar; in the text below the line on fragment L1, however, the distance between the columns is much larger, as if space had been left for the addition of amounts that were not needed in the end..$^{15}$ The distinctive character of the text below the line on L1 shows clearly that there was something different about the information that required that it be separated from the rest of the calendar;
14. Lambert 2002, p. 370.

15. Lambert (2002, p. 358) gives the distance between the left edge of column 2 and column 3 of fragment L1 as approximately $0.20 \mathrm{~m}$. 
in the present fragment, on the other hand, the reason for setting apart this section of the text is not readily apparent.

Beneath the horizontal line is $0.018 \mathrm{~m}$ of uninscribed space. Since the text beneath the line on fragment L 1 begins almost immediately below the line, it is reasonable to conclude that on this fragment too something was originally inscribed here, to the left of the break in the stone. Although the text is not stoichedon, it can be assumed that the left edge of the column was lined up along some kind of margin, an assumption that helps to determine the approximate space available for restoration, in spite of the fact that the haphazard placement of the letters and the tendency to inscribe some of them very close together means that the precise number of letters to be restored is uncertain. The space (enough for ca. 12 letters) is not long enough for a recipient and epithet, but it could have accommodated either an offering or a payment to an officiant. Either restoration would indicate that the first column preserved here was a continuation of one or more preceding columns. It is also possible that the column was headed by a date, which would probably have extended into the left margin. ${ }^{16}$

The restoration of the names and epithets of the deities shows that the lines on the present fragment are much longer than the stoichedon texts on Face A of the other fragments in the group. Since as many as 20 letters could be inscribed (as in line 2), approximately $17 \mathrm{~cm}$ of space must have been available for each line. Where it can be determined, the other fragments have lines with an average of 12 to 13 letters on the Ionic face; on the best-preserved fragment (L3 [Agora I 727]) the lines are a maximum of $12.5 \mathrm{~cm}$ in length. The length of the lines in the text below the horizontal line on fragment $\mathrm{L} 1$ ( $I G \mathrm{II}^{2} 1357$ a [EM 8001 and 6721]) is greater than these, however, containing up to 19 letters. In both L1 and the present fragment, then, the line length is an additional factor that sets the portion of text inscribed below the line apart from that inscribed above.

Unfortunately, neither dates nor any indication of the frequency of sacrifice (annual, biennial, or some other cycle) are preserved on this face. Nevertheless, a few observations can be made about the general context. Apollo is prominent, appearing more than once and under multiple epithets, and the references to Eleusis may help to clarify the context and perhaps identify the festival with which these sacrifices were associated. The emphasis given to the place of sacrifice may also be important, especially since indications of place are rare in the other surviving fragments of the calendar: the only examples are $\dot{\varepsilon} \mu \Pi[v \theta i$ io] (restored on the Attic face of L11 [Agora I 945], line 5) and $\dot{\varepsilon} v \Delta \eta^{\prime} \lambda \omega \mathrm{\imath}$ (on the Ionic face of L8 [Agora I 251], line 6).

There are at least two and probably three references to Apollo in the list of sacrifices. In line 2 he appears with the well-attested epithet Prostaterios. ${ }^{17}$ Reflecting Apollo's role as protector of the city, this title is found

16. For extension of date rubrics into the left margin, see below, p. 51 and n. 44.

17. The epithets Apobaterios (used of Apollo, Zeus, or Theoi), Embaterios (Theoi), and Epibaterios (Theoi) are also consistent with the letters preserved on the stone; see Richard 1988 (SEG XXXIX 1845) for these epithets. Prostaterios, however, best fits the date and the Athenian context. 
in several Greek cities in inscriptions of the Late Classical and Hellenistic periods, and there are literary references as early as Euripides' Elektra.$^{18}$ In Athens, Apollo Prostaterios is frequently found in prytany decrees beginning fairly early in the 3rd century B.c., and, when paired with Artemis Boulaia and ancestral deities, becomes part of a formula of praise for the officials who conducted the customary pre-assembly sacrifices. ${ }^{19}$ The location of his cult site in Athens is unknown. The present text is the earliest epigraphic attestation of the epithet, and shows that Apollo Prostaterios was already well established in Athens by the time the prytany decrees began recording the customary sacrifice offered by the Boule.

Apollo Hupo Makrais (line 4) is best known from the cave sanctuary on the north slope of the Acropolis, where a large number of plaques bearing his name have been discovered, all dating to the first three centuries A.D. ${ }^{20}$ In addition, part of the foundation of what has been identified as a rectangular altar was found in front of the cave during the early excavations, a discovery that establishes a specific location for offerings to this deity. ${ }^{21}$ Until now the only evidence that the cult existed prior to the Roman period was a block of the 6th century B.c. found well below the cave, inscribed with the name of Apollo but lacking an epithet, together with passages in Euripides' Ion indicating a connection between the Long Rocks and Apollo. ${ }^{22}$ The appearance of the epithet in the text published here proves indisputably that the cult existed much earlier than the Roman material alone suggested. It is now clear that Euripides' play reflects cult as well as myth, and that Apollo Hupo Makrais was worshipped by at least the final quarter of the 5 th century B.c.

The mention of the Pythion in line 9 is clear, but the choice of preposition is unusual: normally $\varepsilon^{\prime} v$ would be expected. ${ }^{23}$ The phrase is often preceded by the name of a deity, and Apollo seems an obvious candidate for restoration, considering his association with the Pythion and the pattern of the offerings (see below). The space (ca. 10 letters) may be slightly too long for Apollo, however, and the preposition remains problematic. One possibility is to take the words together as a form of the adjective 'E $\pi \imath \pi v \theta \imath \varsigma$, a compound analagous to 'E $\pi \imath v v \rho \gamma \_\delta i \alpha$, an epithet of Artemis. ${ }^{24}$ Since the deity in question was not in the Pythion, he might instead have been a god whose sanctuary was in the neighborhood of the Pythion and

18. Eur. El. 637. See Themelis 1987, pp. 106-108, for further discussion of the epithet, with a focus on Eretria.

19. Many examples can be found in Agora XV, the earliest of which is no. 78 (273/2 в.c.); see also $S E G \mathrm{XXXIX} 132$. For the practice of inscribing of such decrees, see Lambert 2004b, pp. 86-87. They begin before the 3 rd century, but the earlier ones do not mention Apollo Prostaterios.

20. For the cave, see Travlos, Athens, pp. 91-95, figs. 115-122. Nulton has restudied and catalogued both the inscriptions (2000, pp. 60-195; 2003, pp. 39-88) and the niches in the cave (2000, pp. 196-204). Although the new evidence in the inscription published here requires the modification of some of his arguments, his discussion of the cult in the Roman period (2003, pp. 25-35) is invaluable.

21. Kavvadias 1897, col. 15, pls. 1: $\beta$, 3:I.

22. Meritt 1957, p. 79, no. 24 (Agora I 5577); Eur. Ion 8-19, 283-288, 492506, 936-938.

23. Examples include $\dot{\varepsilon} v \Pi v \theta$ íov

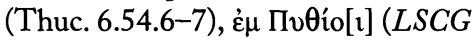

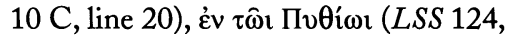

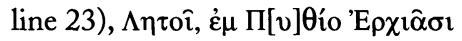
(LSCG $18 \mathrm{~A}$, lines 54-55), and $\Lambda \varepsilon \tau o \hat{,}$ $\grave{\varepsilon} \mu \Pi[v \theta i ́ o]$ (L11 [Agora I 945], line 5). The only other preposition attested is

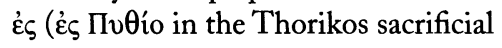
calendar: Daux 1983, line 41), which appears to have the same sense.

24. Artemis Epipurgidia: $I G \mathrm{II}^{2}$ 5050 (Athens, Roman-era inscription at the Theater of Dionysos); SEG XXX 93, lines 10-11 (Eleusis, 20/19 в.с.). The epithet is also attested for Hekate (Paus. 2.30.2). 
who therefore took on this epithet, although such a phenomenon would be unprecedented. If not to be taken as a compound adjective, the words presumably have a spatial significance, indicating a sacrifice to a deity adjacent to the Pythion. An Athenian inscription related to the Thargelia (LSS 14, SEG XXI 469; 129/8 B.c.) may support this interpretation. ${ }^{25}$ The inscription twice mentions activities that take place not within the Pythion itself but in the immediate vicinity of the sanctuary. Games are held [ $\pi \rho]$ ò $\varsigma$

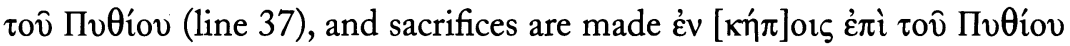
(lines 53-54). Perhaps the use of $\dot{\varepsilon} \pi \dot{\prime}$ in the fragment published here should be understood as part of a formula referring to a similar activity. ${ }^{26}$

There is some debate about the location or locations of the cult center of Apollo Pythios in Athens. The findspot of fragments of the Pythian altar dedicated by Peisistratos the Younger $\left(I G \mathrm{I}^{3} 948\right)$, together with references in Thucydides $(2.15 .4,6.54 .6-7)$, is generally believed to indicate that a $\mathrm{Py}$ thion stood in the vicinity of the Ilissos River, southeast of the Acropolis. ${ }^{27}$ The cave on the north slope of the Acropolis associated with Apollo Hupo Makrais also has considerable support, and some have suggested that both were sites of the worship of Apollo Pythios. ${ }^{28}$ Since the present fragment already mentions Apollo Hupo Makrais in line 4, a reasonable conclusion is that the reference in line 9 is to the Pythion near the Ilissos.

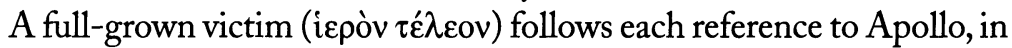
lines 3,5 , and $10 .{ }^{29}$ The same phrase also appears several times in another fragment of the code (L8 [Agora I 251], Face A, lines 5, 8, 10, restored in line 3). This fragment is particularly interesting because it seems to refer to activity connected with Delos, and two of the victims go to Apollo. A third goes to Leto, and the final recipient is not preserved. It is perhaps notable that this particular offering is so often designated for Apollo.

In line 12, Athena Itonia receives a sheep. The Thessalian epithet Itonia is attested in Athens in a catalogue of the treasuries of the other gods ( $I G \mathrm{I}^{3} 383$, lines 151-152; 429/8 B.c.), and in a regulation of cult objects ( $I G \mathrm{II}^{2} 333 \mathrm{c}+\mathrm{e}-\mathrm{f}$, lines 17-18; recently republished in Lambert 2005 , pp. $137-144$, no. 6; probably $335 / 4$ в.c.). ${ }^{30}$ Athenaia, the form of Athena's name restored here, was common at the time and also appears on Face A of other fragments of the calendar (L1 [IG II ${ }^{2} 1357$ a (EM 8001 and 6721)], line 25; L3 [Agora I 727], lines 12, 49; L6 [IG II $1357 \mathrm{~b}$ (EM 286)], lines 1-2; L12 [IG $\left.\mathrm{I}^{2} 845\right]$, line 10). ${ }^{31}$ Offerings to Athena elsewhere in the calendar vary, but three separate sacrifices to Athena on Face A of fragment L3 require sheep (L3 [Agora I 727], lines 12-13, 14-15, 80 ), the third with the price of $12 \mathrm{drachmas}$ preserved. This appears to be

25. For a recent discussion of Apollo in Athens, focusing on Delian Apollo but including Apollo Pythios and his connection to the Thargelia, see Matthaiou 2003, esp. pp. 90-92.

26. I doubt that the use of the dative with the preposition, as opposed to the more regular genitive, is a concern.

27. See Travlos, Athens, pp. 100103 , figs. $130-137$, for the evidence of a Pythion in this area.

28. Most of the discussion revolves around Strabo 9.2.11 (C 404), Philostr. $V S 2.550$, the passages from Euripides' Ion (above, n. 22), and the association of the Pythion with the Olympieion. For a variety of views, see Nulton 2003 , pp. 15-23; Clinton 1973; Travlos, Athens, p. 91; Broneer 1965, pp. 54-62; Wycherley 1959, pp. 68-72; 1963;
Parsons 1943, pp. 234-238.

29. For a brief but useful discussion of this type of offering, see Lambert 2002 , p. 396.

30. For Athena with this epithet in Attica, see Parker 1996, p. 28. For Itonia in nearby Boiotia, see Robertson 2001, p. 52.

31. For the form, see Threatte 1980 , p. 271. 
the standard amount for offerings of sheep to female deities on Face A, but no amount is preserved on the present fragment. ${ }^{32}$

The restoration of bierosyna is fairly secure in lines 11 and 13, where the ending of the word is preserved, but it is possible that line 6 could have held something else, such as a date rubric. Hierosyna, payments to priests or priestesses, normally consisted of the parts of the victim that were the priests' perquisite, but here, as in several other calendars, they are expressed as a cash payment in lieu of part of the animal. ${ }^{33}$ Unfortunately, the amounts of the payments are not preserved on Face A, but see below on Face B, lines 13 and 15, for discussion of the typical amount.

The reference to Eleusis in line 14 naturally calls for restoration of the Eleusinian deities. The offering of a sheep followed by that of a ram (lines 7-8 and 14-16) finds a parallel in other paired sacrifices to Demeter and Kore (Pherrephatte). ${ }^{34}$ This column contains repeated sacrifices to the Goddesses, first in the City Eleusinion (lines 7-8) and then at Eleusis itself (lines 14-16). The term ö $\sigma \tau v$ was typically used to refer to the city as opposed to the countryside, and even, in the case of Athens, to the city as opposed to Piraeus, as shown, for example, by a 3rd-century B.c. regulation of the cult of Bendis in Piraeus ( $L S C G$ 46, lines 8, 12,14, 22, restored in line 29). It was also used in the 4th-century B.c. Erchia calendar to denote sacrifices that took place in central Athens instead of in the deme center of Erchia (LSCG $18 \mathrm{~A}$, line 38). 'Ev ö $\sigma \tau \varepsilon \imath$ is somewhat unusual here: when denoting the sanctuary of the Eleusinian gods in Athens instead of Eleusis,

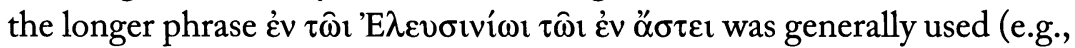
$L S C G 32$, lines 7, 57). Perhaps it was felt that the context, with a mention of the Eleusinian deities and Eleusis itself in the following lines, made the fuller expression unnecessary, and economy of space took precedence over the usual formula.

It is possible that the list of sacrifices of which this column is a part was concerned primarily with Apollo, and that it included offerings to Athena and to the Eleusinian goddesses without, however, focusing on them. A few other fragments of the calendar do mention Eleusinian festivals, but in a more obviously relevant context, in which other deities and officials specifically related to Eleusis appear in addition to Demeter and Kore. ${ }^{35}$ A possible parallel for the association of Apollo and Eleusis may be found in LSS 14 (SEG XXI 469), a lex sacra mentioned above in connection with the Pythion. In it the Eleusinian priests, the hierophant and daduch, are included among participants in the procession for the Thargelia (lines 35-36). If this participation was a regular occurrence at the Thargelia and did not happen only in, or beginning in, 129/8 в.C., the date of the

32. See Lambert 2002, pp. 396-397, for offering amounts.

33. For bierosyna in general and in this calendar in particular, see Lambert 2002, pp. 398-399.

34. $I G \mathrm{II}^{2} 1673$, line 62 (Eleusis, $333 / 2$ в.с.; for the date, see Clinton 1972, pp. 107-113); L3 (Agora I 727), Face A, lines 62-64. The calendar of the Marathonian Tetrapolis (Lambert 2000, col. 2, line 44) contains an offering of a ram for Kore. Healey
(1990, pp. 101-109) discusses the perceived problem of sacrificing a ram, a male animal, for Kore/ Pherrephatte.

35. Two festivals associated with Eleusis, the Eleusinia and the Mysteria, appear in the extant fragments of the calendar. The long list of sacrifices that makes up the third column on the largest fragment has been identified as possibly belonging to the Eleusinia (L3 [Agora I 727], Face A; see Healey 1990 for extensive discussion). The Epidauria, a festival on the third day of the Mysteries, is mentioned on a partially published fragment (L4 [Agora I 7471], Face B; see Clinton 1994, pp. 18-21). Yet another fragment has 'E $\lambda \varepsilon v \sigma i v[--]$, not obviously associated with any particular festival, but mentioned in connection with the Kerykes (L12 [IG I 845], Face A, line 3). 
inscription, it might explain the inclusion of sacrifices to the Goddesses during a celebration of Apollo. The date of the sacrifices recorded in this portion of the calendar might then be the seventh of Thargelion. ${ }^{36}$

One other fragment of the calendar (L3 [Agora I 727]), Face A, lines 115 , may also list sacrifices in the month of Thargelion, if Lambert is correct about the connection with the festival of the Plynteria. ${ }^{37}$ The sacrifices in question immediately precede a column of sacrifices with a biennial rubric, but it is unclear whether they represent the end of an annual sequence or another biennial one. If they were biennial, as Lambert argues, then perhaps the list on the fragment presented here (provided it is also rightly dated to Thargelion) was part of an annual sequence. It must, however, be kept in mind that this is only part of a portion of the entire list, which was carried over from the preceding column and continued below. What has been preserved on the surviving fragment may thus be quite misleading.

\section{FACE B (ATTIC)}

Agora I 7577, Face B

Fig. 3

P.H. 0.33, p.W. $0.123 \mathrm{~m}$

L.H. 0.009; omicron 0.006 m. Stoichos H. ca. 0.011, W. 0.014 m. Interlinear spacing $0.003 \mathrm{~m}$. Space between the left edge of the stone and the text ca. $0.01 \mathrm{~m}$.

410-404 в.с.

Stoich.

abraded vertical surface $0.068 \mathrm{~m}$

$[\ldots 7 \ldots] \mathrm{o}[-.--]$

$[\ldots 8 \ldots] \delta[---]$

$[\ldots 8 \ldots . . . .6[---]$

[...5. . $] \mathrm{o}[---]$

$5 \quad[\ldots 9 . . ..] \delta[---]$

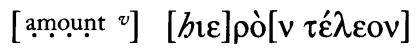

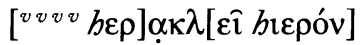

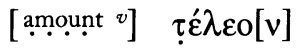

[. .]-[...]o[.]EO[- - - ]

10 [amount] $h\left[\varepsilon^{\prime}\right] \rho o \sigma ı$ [- - epithet? - - offering - - ]

uninscribed vertical surface $0.012 \mathrm{~m}$

36. See Mikalson 1975, p. 153 , for determination of the date of the Thargelia using Plutarch's references to Plato's birthday (Mor. 717B, D).

37. Lambert 2002, p. 374.

11

$11 \mathrm{a}$

15

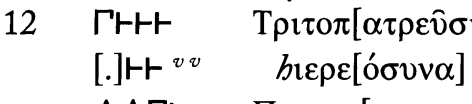

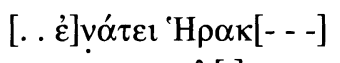

$\lambda[$.

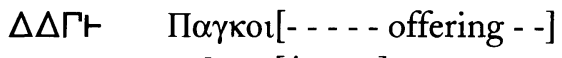

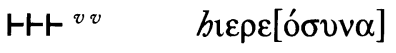

[]$^{v v v} \quad b v \alpha \kappa \imath v[\theta i \sigma 1]$

[amount $]^{v} \kappa \alpha \theta \alpha \rho \mu\left[\right.$ óv$\left.^{2}\right]$

[... . . . ]NA $\Sigma \mathrm{T}\left[-\mathrm{-}^{-}\right]$

[. . 10..... ]ọ[- - - ] 


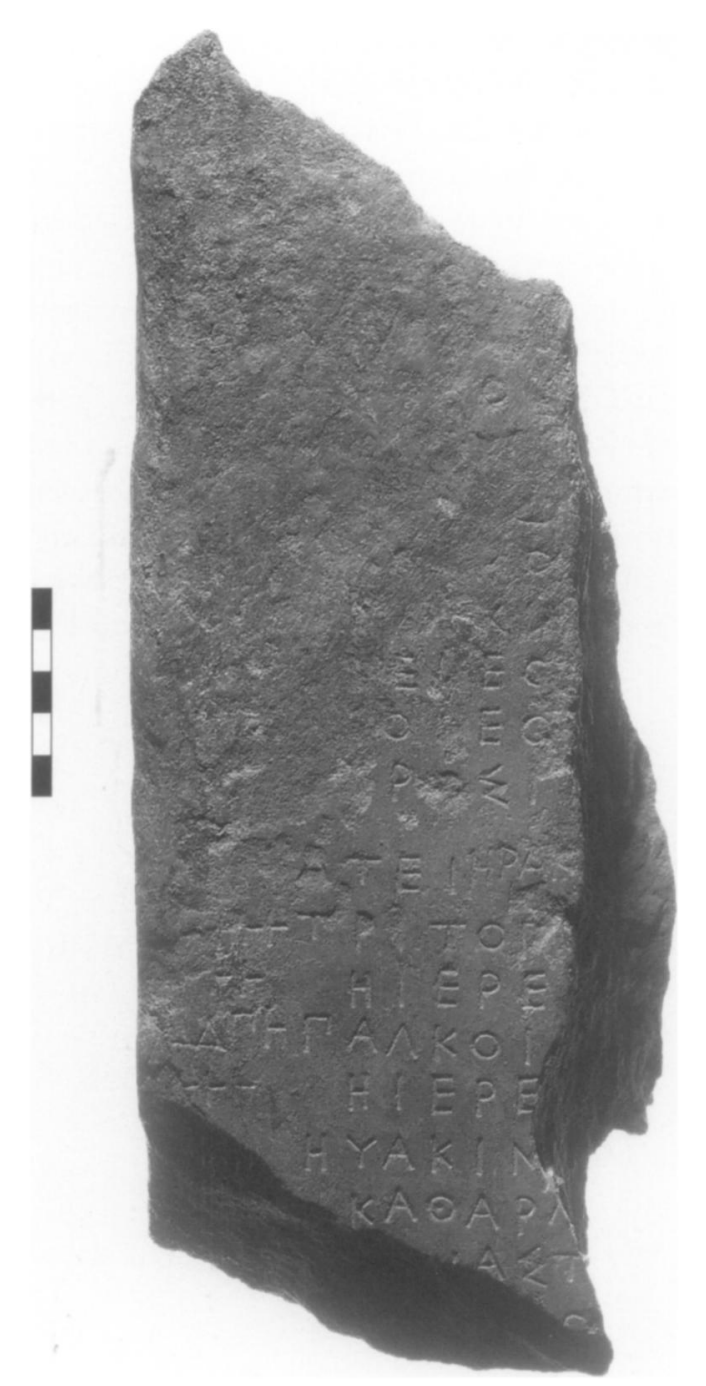

\section{EPigraphical Commentary}

Lines 1-5. Faint traces of letters can be made out throughout the waterworn area at the top, but not enough to distinguish them from stray marks or allow the reading of any additional letters.

Line 4. Most of a battered circular letter can be read in the sixth stoichos.

Line 7. Of the dotted alpha the vague impression of a triangular letter with a faint diagonal stroke sloping up from left to right can be seen. Enough of the angle formed by two diagonal strokes is clear to make the reading of the kappa certain. The lambda has the Attic form.

Line 8. Of the dotted tau the vertical stroke and the right half of the crossing horizontal stroke can be seen just beneath the damaged surface. The Attic lambda has a very clear vertical stroke; the returning upstroke is very damaged, but visible.

Line 9. The remains of a horizontal stroke in the middle of the stoichos and the lower half of a vertical stroke to its left make the reading of the drachma symbol certain.
Figure 3. Agora I 7577, Face B

(Attic). Photo courtesy American School of Classical Studies at Athens, Agora Excavations 
Line 10. In the fifth stoichos the faint traces of a crossbar in the center of the stoichos and a vertical stroke attached to its right make the reading of the Attic heta certain. Part of the upper curve of a round letter is preserved in the eighth stoichos.

Line 11. Of the dotted nu all that remains is the slightest bit of the very bottom of the right vertical stroke.

Beneath line 11 a vertical stroke can be clearly seen, inscribed partially within and partially beneath the space allotted to line 11, between stoichoi 9 and 10. It is followed by a squarish gouge in the stone, ca. $8 \mathrm{~mm}$ long and $7 \mathrm{~mm}$ high, which begins slightly lower than the top of the vertical stroke. From the bottom of the vertical stroke the faint impression of the beginning of a returning diagonal upstroke is visible, making the reading of an Attic lambda likely. The angle created by the upstroke is less than that of the lambda in line 7, but it is difficult to determine whether tighter spacing has led to compression here. In some lights, the faint impression of a horizontal mark extending from the center of the vertical stroke can be discerned, but an epsilon is impossible since there seems to be no room for the upper horizontal stroke. The symbol for drachma is perhaps possible, but much less likely than lambda. Since the gouge in the stone is followed by uninscribed surface, it is clear that no more than two letters could have been inscribed here, and only with a reduced size and spacing, unless the inscription began again after a blank space. The other surviving fragments of the calendar offer no parallel, and what might have been inscribed in such an odd position remains unclear. The letters HPAK directly above are raised slightly above the line, which implies that the stroke and the gouge were already present when the line above was inscribed. The vertical stroke appears to have been deliberately inscribed, and a lambda is the most likely interpretation, although it remains uncertain whether it was meant to be read as part of the text.

Line 13. The Attic heta is used to indicate a rough breathing.

Line 14. The gamma has the Attic form.

Lines 15-16. Both lines contain the Attic heta used to indicate a rough breathing.

Line 17. Of the dotted mu only the bottom of a diagonal stroke sloping down from right to left is preserved.

Line 18. Of the nu in the eighth stoichos the reading of any other letter is precluded by the angle of the two diagonals and the top of a vertical stroke coming from the left diagonal.

Line 19. The top of a round letter is visible in the 11th stoichos.

\section{TransLation}

Sacrifices continuing on unknown day

[for deity], a full-grown offering, [amount]; for Herakles, a full-grown offering, [amount]; for the Heroes [epithet?], [offering], [amount]

On the ninth

for Herakles, [offering and amount?]; for the Tritopatores, [offering], 8 drachmas; hierosyna, [at least 2] drachmas; for Pankoi[- - ], [offering], 26 drachmas; bierosyna, 3 drachmas; for the Hyakinthides, a purification, [amount]; for [deity?], [offering?], [amount?] 


\section{COMMENTARY}

The spacing and overall organization are more careful on Face B, the Attic face, than on Face A. The text is generally stoichedon, although the letters are not always well centered in their individual stoichoi. ${ }^{38}$ The bestpreserved section of the text, the sacrificial list beginning in line 12 , reveals a high level of organization with clear indentations and deliberate spacing. Although other fragments of the calendar place headings in the left margin, no other preserved fragment of Face B uses indentation in a manner similar to this one. Here the names of the recipients begin immediately after the amount column, while other items, such as offerings or payments to officiants, are indented one stoichos, aligned with the second letter of the name of the recipient above and below. A separation is intended between lines 10 and 11, where the interlinear space is ca. $0.012 \mathrm{~m}$, $0.009 \mathrm{~m}$ more than in the remainder of the preserved text. At line 11 , the orderly appearance of the text is broken where HPAK[- - ] seems to have been added later.

The amount of horizontal space given over to this column can be estimated on the basis of the arrangement of the inscribed text. The offering

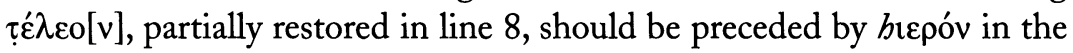
line above. The two-word offering was too long to fit completely into line 7 and so was divided at the word break, with $\tau \dot{\varepsilon} \lambda \varepsilon 0 v$ indented in the line

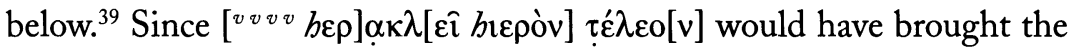
line to the 24th stoichos, it is clear that no more than 23 stoichoi were available. That there were in fact even fewer is shown by lines 16 and 17 , where $\kappa \alpha \theta \alpha \rho \mu[o v$ ], the offering, appears in the line following the recipients, the Hyakinthides. Enough is preserved of the three stoichoi before the name of the Hyakinthides to suggest that no amount was inscribed to the left. ${ }^{40}$ The amount and the offering, indented, follow the recipient in the line below because the offering could not be fitted into the space available

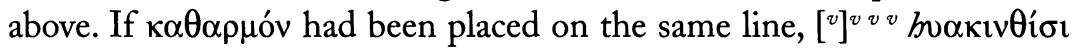
$\kappa \alpha \theta \alpha \rho \mu$ [óv] would have extended to a 22 nd stoichos. It follows, then, that the longest line length deducible from the preserved text, amounts and sacrifices combined, was no more than 21 stoichoi. That there were at least 20 stoichoi is clear from line 12, where enough space must have

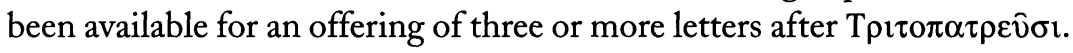
The column therefore consisted of 20 or 21 stoichoi, a length of just under $30 \mathrm{~cm}$. There were, of course, additional columns on the same stone, making the full length of the line significantly greater.

Much less is understood about the organization of the calendar inscribed in the Attic alphabet because much less of it is preserved; the present fragment is therefore especially important because so much of the Attic face survives. It is the only extant fragment of the Attic text that preserves the day on which a sacrifice occurred, and one of only two that preserve amounts in context. ${ }^{41}$ The surviving text includes portions of a sacrificial list, including deities and payments to officiants, for two days of an unknown month. Two offerings are also preserved, and it can be inferred that the other offerings were inscribed to the right of the names of the deities, since amounts are given in a column to the left.
38. They are significantly more centered than the non-stoichedon texts on Face B of the thinner group of fragments, however.

39. It is unlikely that $\tau \varepsilon \dot{z} \lambda$ cov is used alone here as a substantive. Although such a use does appear quite frequently in the calendar from Thorikos (e.g., Daux 1983, lines 22, 24, 26), it is not found elsewhere in the extant fragments of this calendar. See L8 (Agora I 251), Face A, lines 11-12, for the

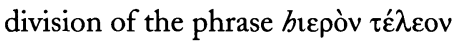
between two lines.

40. Nothing can be said about the first stoichos of this line, however, and it is possible that the amount could have been indicated in only one space (cf. L4 [Agora I 7471], Face B, lines 16, 18, 19).

41. L4 (Agora I 7471), Face B, also contains amounts with sacrifices (see Clinton 1994, pp. 18-21); on L8 (Agora I 251), Face B, only a list of amounts remains. 
After the small uninscribed space following line 10, a date rubric is given in line 11 for the list of sacrifices that follows. The spacing probably indicates a break between one day and the next in the calendar, and since only the day is indicated, the month must have been included in a longer rubric that headed a preceding list. ${ }^{42}$ It should be noted that the date is not followed by an authority rubric, a feature often found on Face A of the calendar but one for which there is as yet no evidence on Face B. This may be an important difference between the two programs of inscribing. ${ }^{43}$ The day, the only one preserved on this face of the calendar, is the ninth ([z]]yó $\tau \varepsilon \imath)$. The use of an ordinal number in the dative is consistent with the way in which the day is written on the Ionic face of the calendar (e.g., L1 [IG II 1357 a (EM 8001 and 6721)], line 3: $\pi \varepsilon ́ \mu \pi \tau \eta \imath)$. The date extends into the left margin, taking up two of the spaces in the amount column. Such an extension is not unusual, as the dates preserved on Face A also extend three spaces to the left. ${ }^{44}$

Although for neither of the days is the list of sacrifices entirely preserved, similarities can be seen both within and between the days. Most of the recipients are heroes and other venerated dead, and there are two references to Herakles. Several of the deities are known from other Attic calendars and inscriptions, and in some cases even the locations for the cult are known.

Only two recipients and their offerings are preserved at the end of the list for the first day. In line 7, Herakles is named as a recipient of a biepòv $\tau \varepsilon ́ \lambda \varepsilon$ cov (see p. 45, above, Face A, lines 3, 5, and 10, for discussion of this phrase). Too many festivals and sacrifices to Herakles are known from Attica to permit much speculation about the context of this particular offering. ${ }^{45}$ He may have received sacrifices on the fourth of every month along with Hermes and Aphrodite, although the very late evidence for this practice may not be valid for the Classical period. ${ }^{46} \mathrm{~A}$ 1st-century A.D. Attic calendar includes a sacrifice to Herakles on the second of Mounichion (LSCG 52, lines 26-27), and the sacrificial list of the Salaminioi (Rhodes and Osborne 2003, pp. 184-188, no. 37, line 86) records another on an unknown day of the same month. Another inscription related to the Salaminioi (Lambert 1997, pp. 88-89, no. 2, line 2) mentions a festival of Herakles in Mounichion as well. The Thorikos calendar (Daux 1983, line 36) lists a sacrifice to him in Elaphebolion, but again no date is specified. Finally, a festival of Herakles mentioned by Demosthenes (19.125) can be placed in early Hekatombaion.

Heroes are the final recipients listed for the first day (line 10). Although precise parallels for a sacrifice to the heroes as an anonymous group are difficult to find, a similar offering to a group of heroines is mentioned in a 3rd-century B.c. regulation enacted by a private association in Athens (LSS 20, line 14). ${ }^{47}$ In that case, however, the context helps to clarify which group of heroines is meant. In the same way, context or an epithet no longer preserved probably indicated that this sacrifice was not to all the heroes, but to a specific group. ${ }^{48}$

At least three recipients of sacrifice on the following day are preserved. The restoration of Herakles in line 11 seems certain, although of the known Attic festivals and sacrifices to this hero, none is specifically associated with the ninth of the month. The line is problematic because the 
space available for the offering and amount is severely limited. Although there may have been room for an offering inscribed after the name on the same line, especially with the reduced letter size and spacing, there does not appear to be any space in which to record the price. Also worthy of note is the spelling of the name (HPAK-), in which $\mathrm{H}$ is used in the Ionic fashion, as a vowel rather than an aspirate. ${ }^{49}$ The use of Ionic letters in an otherwise Attic document is not unusual, and Ionic eta is particularly common even in official documents before the change of alphabet in 403 B.C. ${ }^{50} \mathrm{It}$ is unlikely that the $\mathrm{H}$ represents a syllabic [HE] sound, as it usually does in central Ionic dialects and occasionally in Attic dipinti: to date, there is only one other questionable example known of this use in an Attic inscription, on a 4th-century B.c. horos, also in the name Herakles. ${ }^{51}$ It is possible that the inscriber deliberately wrote Herakles in this way to save space, since an eta requires less space than an eta and epsilon. If so, it would suggest that he was making a conscious choice from the multiple alphabets at his disposal..$^{52}$ (For discussion of the relationship between this line and line 11a, see the epigraphical commentary above.)

In line 12 the Tritopatores receive an offering, which was most likely inscribed just beyond the break in the stone. These ancestral figures were venerated throughout the Greek world, making a notable appearance in the sacred law from Selinous. ${ }^{53}$ Horoi attest to local cults of the Tritopatores in many of the Attic demes, and sacrifices to them are recorded in a few local calendars: in Erchia they were honored on the 21st of Mounichion (LSCG $18 \mathrm{D}$, line 41-46), and the Tetrapolis calendar lists both annual and biennial sacrifices in Skirophorion to be made at the Skira festival (Lambert 2000, col. 2, lines 32 and 53-54). ${ }^{54}$ Inscriptions identify their shrine at a crossroads in the Kerameikos, placing them in a prominent position among the dead in the cemetery of Athens..$^{55}$

There is no known deity whose name fits the letters preserved in line 14.

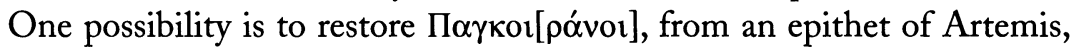

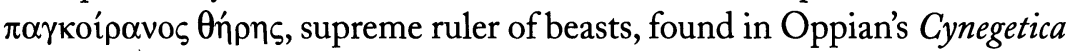
(4.21). It would be unusual to find an epithet standing alone, however, without the name of a deity. The adjective $\pi \alpha$ ' $\gamma$ кotvo $\varsigma$, used by the tragedians in euphemistic expressions for death (Aesch. Sept. 608, Soph. El. 138), and the similar $\pi \alpha \gamma$ кoí $\tau$, used for the grave (Soph.Ant. 804), are possibilities that fit the character of this portion of the sacrificial list. Both words appear only in poetry, however, and the use of one of them here as either an epithet or a personification, while not impossible, seems unlikely.

Hierosyna are recorded in lines 13 and 15 (cf. Face A, lines 6, 11, 13). The indentation created by the blank space before the word indicates that this sum is meant to be associated with the deity listed in the line above, as payment for the priest who presided over the sacrifice. ${ }^{56}$ Five bierosyna are recorded on the Ionic face of two other fragments of the calendar: L3 (Agora I 727), lines 4, 23, 39, 52; and L6 (IG II 1357 b [EM 286]), line 6. The amounts of two of these are preserved: one (L3, line 39) is four drachmas and two obols, and associated with the sacrifice of a sheep priced at only four drachmas; the other (L3, line 52) is 16 drachmas, and associated with a larger sacrifice of two bovines priced at 50 drachmas. On the fragment
49. Elsewhere on this face (lines 10 , 13,15 , and 16 , restored in lines 6 and 7) the $\mathrm{H}$ has its normal Attic value.

50. See Threatte 1980, pp. 41 and 49, for Ionic forms in Attic documents before 403 в.c.

51. See Threatte 1980, pp. 45-47, on $\mathrm{H}$ for [HE]. I thank Professor

Threatte for taking the time to discuss this issue with me.

52. Compare the mix of forms used in fragment L9 (Agora I 687), Face B, line 6 (mentioned by Lambert 2002, p. 381).

53. Jameson, Jordan, and Kotansky 1993, pp. 14-17, col. A, lines 9-10, 13.

54. For discussion and a list of evidence from the ancient Greek world, see Jameson, Jordan, and Kotansky 1993, pp. 107-114.

55. See Knigge 1991, pp. 103-105, for the Tritopatreion in the Kerameikos.

56. In other sacrificial calendars bierosyna similarly follow the sacrifices with which they are associated. Cf., e.g., the calendar of the Marathonian Tetrapolis (Lambert 2000), esp. col. 2, line 32, where the bierosyna are associated with the Tritopatores. 
published here only one amount is fully preserved: three drachmas at line 15 . The differences among the three figures reflect the variation in the amount of such payments. In general, it seems that the amount of the bierosyna was often related to the type of victim offered. ${ }^{57}$ In line 14, the offering itself is not preserved, but its price of 26 drachmas seems to indicate that it was more substantial than the relatively small bierosyna would suggest.

The final recipients of sacrifice whose name is preserved are the Hyakinthides (line 16). These sisters became the object of cult after being sacrificed for the good of Athens, although sources disagree on their number and their names. ${ }^{58}$ Two main versions of the story exist. According to the fragments of Euripides' Erechtheus, the Hyakinthides were the daughters of Erechtheus, who became goddesses after their deaths were required during the Eleusinian war. ${ }^{59} \mathrm{~A}$ similar story appears in [Apollodoros] 3.15.8, but there they are identified as the daughters of Hyakinthos, a Spartan living in Athens, who were sacrificed during a siege of the city by Minos. Face B of Agora I 7577 contains the only extant epigraphical reference to the Hyakinthides themselves, although their cult site, the Hyakinthion, is mentioned in a document detailing a restoration of shrines in Attica during the Augustan period ( $I G \mathrm{II}^{2} 1035$, line 52).${ }^{60}$ The details about their cult given in the Erechtheus chiefly concern offerings and the nature of the

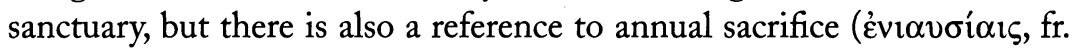
65 , line 78). It is not entirely clear that the Attic face of the calendar was organized by frequency of sacrifice, as the Ionic face was, but if so, this passage may suggest that the present fragment formed part of the list of annual sacrifices. Here they receive a $\kappa \alpha \theta \alpha \rho \mu$ [óv], a purificatory offering (line 17).

57. Loomis (1998, pp. 76-87) lists the Attic examples of both bierosyna and apometra and concludes that no definitive trends can be deduced.

58. For discussion of the cult of the Hyakinthides, see Larson 1995 , pp. 102, 122-123; Kearns 1989, pp. 5963, 201-202.

59. Austin 1968, pp. 30-40, frr. 60 and 65 .

60. See Culley 1975 for a new edition of the text and a discussion of its date. In his treatment of the topographical issues raised by the inscription, Culley proposes the Hill of the Muses as the site of the Hyakinthion (1977, p. 286, n. 14, with additional bibliography).

61. The text below the inscribed horizontal line on the Ionic face contains at least one sentence ( $\mathrm{L} 1\left[I G \mathrm{II}^{2}\right.$ 1357 a (EM 8001 and 6721)], Face A, lines 26-27), and the poorly preserved Attic face of another fragment (L9 [Agora I 687], Face B) probably does as well; see Lambert's commentary on L9 (2002, p. 389).
Line 18 is difficult to restore with confidence. What one expects is an amount followed by the name of a deity and an offering. One possibility is $v \alpha \sigma \tau$ ó $\varsigma$, a kind of cake that appears as an offering in $I G \mathrm{II}^{2} 1366$, line 23, and 1367 , line 14 (both dated to the 1st century A.D.). If four spaces are allowed for the amount, however, this restoration would leave only three spaces for the name of the deity. $\Delta \mathrm{u}^{\prime}$ is possible, and is perhaps supported

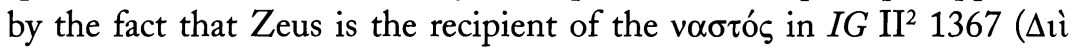
$\Gamma \varepsilon \omega \rho \gamma \hat{\omega}$, line 12).

A second, less attractive, possibility is [’̉]v ö $\sigma \tau[\varepsilon 1]$ (cf. p. 46, above, Face A, line 7, with commentary). This restoration does not fit the pattern of indentation set by the lines above. Although it is not clear that indentation is an absolute necessity here, especially since only a few lines are preserved, the prepositional phrase "in the city" is unexpected and does not make sense by itself; if correct, it must, therefore, be part of a longer passage of text. Full sentences do appear elsewhere in the calendar and it is possible that the text was not in calendrical form at this point. ${ }^{61}$

The chthonic nature of the recipients of sacrifice in these two lists may explain why they are grouped together on two consecutive days. The sacrifices were perhaps part of a celebration honoring heroes and other important dead and extending over a period of several days. The second list, at least, was probably associated with a festival of Herakles, and gives some idea of what that festival may have entailed. 


\section{CONCLUSIONS}

As in the case of any fragmentary text, each new find makes a welcome contribution to the whole. Even if the fragment presented here were not part of such an important document, it would still be a significant inscription in its own right. The texts provide information about several little-known deities and epithets, and shed new light on more familiar ones. They contain the earliest epigraphic attestation for Apollo Prostaterios (Face A) and the only one for the Hyakinthides (Face B). Face A reveals concrete evidence for the worship of Apollo Hupo Makrais in the 5th century and contributes to the debate about the location of the cult center of Apollo Pythias. Furthermore, this fragment differs from the other extant fragments of the code in meaningful ways, complicating and enriching the picture of the whole. This is the only fragment whose Attic text preserves a day on which sacrifice occurred, and one of two that preserve amounts in context. It also displays interesting alphabetic, orthographic, and compositional features, such as the attention to spacing and indenting on Face B not found on any other published fragment of the code.

Despite these additions to our knowledge, it must be remembered that only a small fraction of the calendar is preserved. The advances brought by the publication of this new fragment have revealed how little is known about the nature of the code as well as about certain aspects of Greek cult. This text thus should be regarded as a caveat, as well as a pleasant reminder, that much more remains to be discovered.

\section{REFERENCES}

Agora XV = B. D. Meritt and J. S. Traill, Inscriptions: The Athenian Councillors (Agora XV), Princeton 1974.

Austin, C., ed. 1968. Nova Fragmenta Euripidea in Papyris Reperta, Berlin.

Broneer, O. 1965. "Notes on Three Athenian Cult Places," ArchEph 1960, pp. 54-67.

Clinton, K. 1972. "Inscriptions from Eleusis,” ArchEph 1971, pp. 81-136.

- 1973. "Apollo, Pan, and Zeus, Avengers of Vultures: Agamemnon, 55-59," AJP 94, pp. 282-288.

. 1982. "The Nature of the Late Fifth-Century Revision of the Athenian Law Code," in Studies in Attic Epigraphy, History, and Topograpby Presented to Eugene Vanderpool (Hesperia Suppl. 19), Princeton, pp. 27-37.

1994. "The Epidauria and the Arrival of Asclepius in Athens," in Ancient Greek Cult Practice from the Epigraphical Evidence. Proceedings of the Second International Seminar on
Ancient Greek Cult, Organized by the Swedish Institute at Athens, 22-24 November 1991 (SkrAtb 8, 13), ed. R. Hägg, Stockholm, pp. 17-34.

Culley, G. R. 1975. “The Restoration of Sanctuaries in Attica: I.G., $\mathrm{II}^{2}$, 1035," Hesperia 44, pp. 207-223.

- 1977. "The Restoration of Sanctuaries in Attica, II: The Structure of $I G \mathrm{II}^{2}, 1035$ and the Topography of Salamis," Hesperia 46, pp. 282-298.

Daux, G. 1983. "Le calendrier de Thorikos au Musée J. Paul Getty," AntCl 52, pp. 150-174.

Dow, S. 1960. “The Athenian Calendar of Sacrifices: The Chronology of Nikomachos' Second Term," Historia 9, pp. 270-293. . 1961. "The Walls Inscribed with Nikomakhos' Law Code," Hesperia 30, pp. 58-73.

Fingarette, A. 1971. "A New Look at the Wall of Nikomakhos," Hesperia 40 , pp. $330-335$. 
Healey, R. F. 1990. Eleusinian Sacrifices in the Athenian Law Code, New York.

Jameson, M., D. R. Jordan, and R. D. Kotansky. 1993. A Lex Sacra from Selinous (GRBM 11), Durham.

Jourdain-Annequin, C. 1998. "Public ou privé? À propos de quelques cultes d'Héraclès dans la cité grecque," Ktema 23, pp. 345-364.

Kavvadias, Р. 1897. "Толоүр

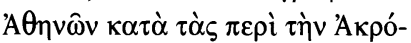

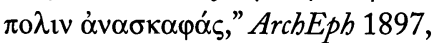
cols. 1-32.

Kearns, E. 1989. The Heroes of Attica (BICS Suppl. 57), London.

Knigge, U. 1991. The Athenian Kerameikos: History, Monuments, Excavations, trans. J. Binder, Athens.

Lambert, S. 1997. "The Attic Genos Salaminioi and the Island of Salamis," ZPE 119, pp. 85-106.

- 2000. "The Sacrificial Calendar of the Marathonian Tetrapolis: A Revised Text," ZPE 130, pp. 43-70.

- 2000-2003. "Two Documents of Attic Gene," Horos 14-16, pp. 7782.

- 2002. "The Sacrificial Calendar of Athens," BSA 97, pp. 353399.

- 2004a. "Greek Inscriptions in the University Museum, Oxford, Mississippi," ZPE 148, pp. 181186.

-2004b. "Athenian State Laws and Decrees, 352/1-322/1: I.

Decrees Honouring Athenians," ZPE 150, pp. 85-120.
2005. "Athenian State Laws and Decrees, 352/1-322/1: II. Religious Regulations," ZPE 154, pp. 125-159.

Larson, J. 1995. Greek Heroine Cults, Madison.

Loomis, W. T. 1998. Wages, Welfare Costs, and Inflation in Classical Athens, Ann Arbor.

Matthaiou, A. 2003. "A $\pi$ ó $\lambda \lambda \omega v \Delta \dot{\eta} \lambda$ ios

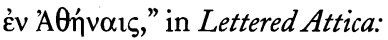
A Day of Attic Epigraphy. Proceedings of the Athens Symposium, March 2000 (Publications of the Canadian Archaeological Institute at Athens 3), ed. D. Jordan and J. Traill, Athens, pp. 85-93.

Meritt, B. D. 1957. "Greek Inscriptions III: Decrees and Other Texts," Hesperia 36, pp. 51-97.

Mikalson, J. D. 1975. The Sacred and Civil Calendar of the Athenian Year, Princeton.

Nulton, P. E. 2000. "The Cave Sanctuary of Apollo Hypoakraios on the Acropolis North Slope: Politics and Religion in Imperial Age Athens" (diss. Brown Univ.).

- 2003. The Sanctuary of Apollo Hypoakraios and Imperial Athens (Archaeologia Transatlantica 21), Providence.

Parker, R. 1996. Athenian Religion: $A$ History, Oxford.

-2005. Polytheism and Society at Athens, Oxford.

Parsons, A. W. 1943. "Klepsydra and the Paved Court of the Pythion," Hesperia 12, pp. 191-267.
Rhodes, P. J., and R. Osborne. 2003. Greek Historical Inscriptions, 404323 B.C., Oxford.

Richard, F. 1988. "Les souverains en 'theoi epibaterioi.' Sur un aspect particulier du culte impérial," in Navires et commerces de la Méditerranée antique: Hommage à Jean Rougé (Cahiers d'histoire 33.3-4), Lyons, pp. 441-452.

Robertson, N. 1990. "The Laws of Athens, 410-399 в.c.: The Evidence for Review and Publication," JHS 110, pp. 43-75.

- 2001. "Athena as Weather Goddess: The Aigis in Myth and Ritual," in Athena in the Classical World, ed. S. Deacy and A. Villing, Leiden, pp. 29-55.

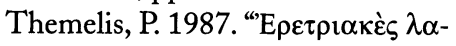

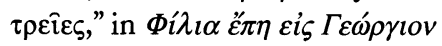
E. $M v \lambda \omega v \hat{\alpha} v 2$, Athens, pp. 106125.

Threatte, L. 1980. The Grammar of Attic Inscriptions 1: Phonology, Berlin.

Todd, S. 1996. "Lysias against Nikomachos: The Fate of the Expert in Athenian Law," in Greek Law in Its Political Setting: Justifications, Not Justice, ed. L. Foxhall and A. D. E. Lewis, Oxford, pp. 101131.

Wycherley, R.E. 1959. "Two Athenian Shrines," AJA 63, pp. 67-72. - 1963. "The Pythion at Athens: Thucydides 2.15.4; Philostratos, Lives of the Sophists 2.1.7," AJA 67, pp. 75-79.

\section{Laura Gawlinski}

Wilfrid Laurier UNiversity

DEPARTMENT OF ARCHAEOLOGY AND CLASSICAL STUDIES

WATERLOO, ONTARIO N2L 3C5

CANADA

lgawlinski@wlu.ca 